\title{
LOSONCZ MIKLÓS
}

\section{A gazdasági és monetáris unió fenntarthatóságának néhány kérdése}

\begin{abstract}
A tanulmány a gazdasági és monetáris unió (Economic and Monetary Union, EMU) eddigi és várható fejlődési irányzatait a fenntarthatóság mint elméleti keret és gazdaságpolitikai gyakorlat alapján elemzi. A fenntarthatóság érvényesülését az optimális valutaövezettel, a 2008-ban kezdődött nemzetközi pénzügyi és gazdasági, majd az európai uniós szuverén adósságválság kezelésével, valamint mindettől elválaszthatatlanul a gazdasági és monetáris unió müködési és szerkezeti gyengeségeinek kiküszöbölését, illetve enyhítését célzó reformokkal összefüggésben tárgyalja. Ez utóbbiakba tagállami szinten beleérti a fenntartható gazdasági növekedést és a modernizációt szolgáló szerkezeti reformokat, euróövezeti szinten pedig a fenntartható gazdasági konvergenciát és a gazdasági sokkokkal szembeni rugalmas ellenálló képességet. A tanulmány egyik leglényegesebb következtetése, hogy a megelözés mellett szükség van integrációs szintü ex post korrekciós válságkezelő eszközök, források és mechanizmusok kidolgozására.* Journal of Economic Literature (JEL) kód: F15, F45.
\end{abstract}

Fennállásának első tíz évében, a kedvező világgazdasági konjunktúra időszakában többé-kevésbé kielégítően müködött a gazdasági és monetáris unió (GMU), sőt egyfajta sikertörténetnek volt tekinthető. Ez tükröződött az Európai Bizottságnak az euró bevezetésének 10. évfordulójára készített értékelésében (EC [2008]). A 2008-2009. évi nemzetközi pénzügyi és gazdasági válság azonban felszínre hozta az euróövezet müködési és szerkezeti gyengeségeit. Ennek nyomán vetődtek fel a GMU hosszú távú életképességével kapcsolatos kételyek, amelyek hosszabb-rövidebb időre a válság

* A tanulmány az MTA-BGE Makrogazdasági fenntarthatósági kutatócsoport mint munkahely keretében, a Magyar Tudományos Akadémia Támogatott Kutatócsoportok Irodájának támogatásával készült. A szerző a munkacsoport vezetője. A mű a KÖFOP-2.1.2-VEKOP-15-2016-00001 azonosítószámú, A jó kormányzást megalapozó közszolgálat-fejlesztés elnevezésű kiemelt projekt keretében működtetett Ludovika Kiemelt Kutatóműhelyben, a Nemzeti Közszolgálati Egyetem felkérésére készült. A cikk alapját képező tanulmány megjelenik a Halmai (szerk.) [megjelenés alatt] kötetben.

Losoncz Miklós DSc. egyetemi tanár, Budapesti Gazdasági Egyetem Pénzügyi és Számviteli Kar (e-mail: Losoncz.Miklos@uni-bge.hu).

A kézirat első változata 2019. április 3-án érkezett szerkesztőségünkbe.

DOI: http://dx.doi.org/10.18414/KSZ.2019.5.478 
utáni tíz évben is felerősödtek. A GMU fenntarthatóságát megkérdőjelezhetik, illetve az azzal kapcsolatos bizonytalanságot fokozhatják az utóbbi években egyre jelentösebbé váló euroszkeptikus és eurofób politikai erők.

A GMU fennmaradását és müködését veszélyeztető kihívásokra az érintett európai uniós intézmények és tagállamok által adott válaszok egyik része a körülmények nyomására született, rövid távra szólt, tüneti kezelést jelentett, másik részük azonban módszeres intézményfejlesztésnek tekinthető. Ugyanakkor sok alapvető kérdésről még folynak a viták, és kétséges, hogy ezekben mikor jutnak döntésre a tagállamok.

A működési és szerkezeti gyengeségek feltárásáról, az eddigi intézkedések értékeléséről és a gazdasági és monetáris unió reformjáról, illetve elmélyítéséről nagyszámú tanulmány született, az erről szóló nemzetközi és hazai szakirodalom folyamatosan gyarapodik. Részben ezekre a szakértői véleményekre támaszkodva az európai uniós intézmények is elkészítették javaslataikat.

$\mathrm{Az}$ elemzések jelentős részében elméleti háttérként, az európai uniós joganyagra való utalás és gazdaságpolitikai követelmény formájában kimondva vagy kimondatlanul, megjelenik a fenntarthatóság. Ennek az írásnak a célja éppen ez: a GMU fenntarthatóságával kapcsolatos leglényegesebb kérdések áttekintése, értelmezése és elemzése, következtetések levonása.

Először a fenntarthatóságra vonatkozó általános szemléleti kereteket vázoljuk fel, majd a fenntarthatóság fogalmát az Európai Unióra, illetve a GMU-ra alkalmazzuk. Ezután az optimális valutaövezetet mutatjuk be a fenntarthatóság szempontjából, majd a válságkezeléssel és a GMU kiteljesítésével kapcsolatos legfőbb kérdéseket elemezzük. Külön pontban tárgyaljuk a fenntarthatóság és a reformok összefüggéseit. A tanulmányt az összefoglalást és következtetéseket tartalmazó fejezet zárja.

\section{Általános szemléleti keretek}

Az ENSZ Környezet és Fejlődés Világbizottságának (World Commission on Environment and Development, WCED) a Közös jövőnk címü, 1987-ben elfogadott jelentésében (Brundtland-jelentés) szereplö, legszélesebb körben elfogadott definíció szerint a fenntartható fejlődés „olyan fejlődés, amely úgy elégíti ki a jelen igényeit, hogy nem rontja a jövő nemzedékek képességét saját igényeik kielégítésére" (WCED [1987] 43. o.). A jelentés, amelynek középpontjában a generációk közötti tehermegosztás áll, meghatározta azokat az elveket és követelményeket, amelyek érvényre juttatása esetén a földi élet megőrizhető a jövő generációi számára.

Hétköznapi szóhasználattal fenntarthatónak azt tekintjük, ami tartósan életképes - és ezt az egyszerü megfogalmazást bátran alkalmazhatjuk a gazdasági és monetáris unióra. A fenntartható fejlődés értékválasztás is, amelynek alapján a terhek jelen- és jövőbeli generációk közötti elosztásának elveit és az elosztás mértékét meghatározzák.

A gazdasági integrációk fenntarthatóságához kapcsolódó fogalom a reziliencia, valamint a stabilitás és az egyensúly. ${ }^{1}$ A reziliencia (resilience) általános értelemben

\footnotetext{
${ }^{1}$ A következőkben az ellenálló képesség kifejezést használjuk a reziliencia szó helyett.
} 
rugalmasság, a külső sokkokkal szembeni ellenálló képesség. A stabilitás általános értelemben állandóságot jelent, amely a rendszerek élettartamára vonatkozó definíció alapján a fenntarthatóság szükséges, de nem elégséges feltétele. A rendszerelmélet szerint egy rendszer akkor van a folyamatos egyensúly állapotában, ha tényezőinek aktuális konfigurációja alkalmas arra, hogy környezetéhez alkalmazkodva önmagát fenntartsa. Ez a fogalom tartalmazza az ellenálló képesség követelményét is. $\mathrm{Az}$ egyensúly a fenntarthatóságnak szintén szükséges, de nem elégséges feltétele. Az integrációk fenntarthatóságához kapcsolódik a kohézió fogalma is, amelynek jelentése összetartozás, összetartó erő. Ennek hiányában az integrációban részt vevő országok az „,egyre szorosabb unió” létrehozása helyett könnyen eltávolodhatnak egymástól, ami a közösség szétrobbanásához is vezethet.

\section{A fenntarthatóság az Európai Unióban, illetve a GMU-ban}

A fenntarthatóság és a fenntartható fejlődés az Európai Unióban is kiemelkedő fontosságú hosszú távú gazdaság-, környezet- és társadalompolitikai célkitűzés, amely először az 1997-ben aláírt amszterdami szerződésben jelent meg, és része maradt az alapszerződések későbbi változatainak is. A fenntartható fejlődést 2001 júniusában Göteborgban tartott ülésén az Európai Tanács a 2000. évi lisszaboni stratégia kiegészítéseként fejlesztette stratégiává. A fenntartható fejlődés hatályos stratégiája a Brundtland-jelentés definícióján alapul, és egymással szoros összefüggésben kezeli a fenntarthatóság gazdasági, társadalmi és környezeti dimenzióját.

Az elsődleges jogforrásokban a fenntartható fejlődést általános követelményként az Európai Unióról szóló szerződés (EUSZ) 3. cikkének 3. bekezdése tartalmazza, amely szerint:

„Az Unió egy belső piacot hoz létre. Az Unió Európa fenntartható fejlődéséért munkálkodik, amely olyan kiegyensúlyozott gazdasági növekedésen, árstabilitáson és magas versenyképességű, teljes foglalkoztatottságot és társadalmi haladást célul kitűző szociális piacgazdaságon alapul, amely a környezet minőségének magas fokú védelmével és javításával párosul. Az Unió elősegíti a tudományos és műszaki haladást.”2

Ebből az következik, hogy a fenntartható fejlődés az Európai Unió jogilag kötelező célkitűzése. Többek között éppen az EU fenntarthatósági stratégiájától és fenntartható gazdasági fejlődésétől várható az európai integráció fennmaradása.

Az Európai Unió müködéséről szóló szerződésben a fenntarthatóság gazdasági dimenziója a gazdaság-, a monetáris és a költségvetési politikával összefüggésben szerepel. Az ezzel szembeni követelmények egyaránt vonatkoznak az EU-ra és a GMU-ra. Egy lehetséges meghatározás szerint

„a költségvetési politika akkor tekinthető fenntarthatónak, ha a jövőben felmerülő elsődleges többletek összegének jelenértéke megegyezik a most, a jelenben mért államadósság szintjével, vagyis elöbbi fedezi az utóbbit" (Benczes-Kutasi [2010] 67. o.).

\footnotetext{
${ }^{2}$ https://eur-lex.europa.eu/legal-content/HU/TXT/?uri=CELEX\%3A12012M003.
} 
E feltétel érvényesülése esetén nem következik be államcsőd. A folyamatosan nagy költségvetési hiány és az annak nyomán emelkedő államadósság-ráta miatt a finanszírozási feltételek egyre nehezebbé, sőt egy ponton lehetetlenné válnak. Az eladósodás növekedéséhez vezető költségvetési politika nem fenntartható, azaz nem folytatható a végtelenségig. A részletek bemutatása és a teljesség igénye nélkül érdemes kiegészíteni a fentieket azzal, hogy adott államadósság-ráta fenntarthatósága még a GDP növekedési ütemének és a reálkamatlábnak is a függvénye.

A maastrichti szerződés kidolgozói a GDP-arányos költségvetési deficit 3 százalékos felső határértékének kialakításakor abból indultak ki, hogy a költségvetés folyó bevételeinek fedezniük kell a folyó kiadásokat. A folyó költségvetési tételek esetében a deficitfinanszírozás lehetőség szerint elkerülendő. Hitelből történő finanszírozás csak az állami-közületi szektornak a több generációt szolgáló vagy vagyonnövekedést eredményező beruházásai esetében megengedett, aminek nagyságrendje a GDP legfeljebb 3 százaléka lehet. Ez az úgynevezett aranyszabály. Ez a követelmény nem egy-egy évre, hanem a konjunktúraciklus egészére vonatkozik, azaz a konjunktúraciklus átlagában kell megfelelni neki.

A beruházások folyó bevételekből történő finanszírozása azt jelenti, hogy a jelen generáció fizet a jelen kiadásaiért még akkor is, ha a jelenben eszközölt kiadások, pontosabban beruházások eredményei közép- vagy hosszú távon lesznek érzékelhetők. A hatékonyság és a méltányosság azonban azt kívánja, hogy a közpénzből finanszírozott beruházásokért (útépítés, környezetvédelem stb.) részben azok a jövőbeli generációk is fizessenek, amelyek szintén élvezni fogják e beruházások hasznát. Az viszont megengedhetetlen, hogy kizárólag a jövő generációi fizessenek azokért az előnyökért, amelyeket a jelen generációja élvez (Pisani-Ferry [2002] 15. o.). Az aranyszabály összhangban van a fenntarthatóság értékválasztáskénti felfogásával, mert biztosítja a generációk közötti méltányos tehermegosztást azáltal, hogy a közberuházások jelenbeli költségeit vagy azok egy részét hitelből fizetik ki, amelyet a jövőben törlesztenek.

A GDP-arányos bruttó államadósság nagysága jó közelítéssel kifejezi a pénzügyi terhek jelenlegi és jövőbeli generációk közötti elosztását. A maastrichti szerződés elfogadása idején uralkodó feltételek között maximum 3 százalékos GDParányos államháztartási hiány esetében a legfeljebb 60 százalékos GDP-arányos bruttó államadósság hosszú távon fenntarthatónak bizonyult. ${ }^{3}$ Annak ellenére, hogy azóta a körülmények átalakulásával ezek a küszöbértékek is módosultak, az eredeti költségvetési kritériumokat változatlanul hagyták, legfeljebb az értelmezésüket finomították.

Az Európai Unióról szóló szerződés a gazdasági tevékenységek csak olyan bővülését tekinti fenntarthatónak, amely nem inflációgerjesztő. A magas szintủ foglalkoztatottság és szociális védelem is csak akkor valósítható meg, ha a gazdasági növekedés nem gerjeszt inflációt. Mindez egyben a monetáris politikának a fenntarthatóság

\footnotetext{
${ }^{3}$ A túlzott eladósodás gazdasági növekedésre és egyéb makrogazdasági mutatókra gyakorolt kedvezőtlen hatásaival foglalkozó írások közül különösen nagy visszhangot váltottak ki C. Reinhart és K. Rogoff munkái (Reinhart-Rogoff [2010], [2011], [2013]).
} 
biztosításában betöltött szerepére is felhívja a figyelmet, azaz az Európai Központi Banknak (EKB) és az eurót nem használó tagállamok központi bankjainak is törekedniük kell az árstabilitás fenntartására.

Ez az értelmezés azon az 1970-es évtizedben elfogadott és bizonyított hipotézisen alapul, amely szerint a hosszú távon fenntartható termelést, illetve annak ütemét (ez egyben a potenciális termelés, illetve annak üteme) a termelési tényezők (munkaerő, tőke) mennyisége és minősége (a foglalkoztatottak száma, növekedési üteme, szakképzettség, motiválhatóság, beruházás, műszaki fejlődés, teljes tényezőtermelékenység) határozza meg.

A nem inflációgerjesztő növekedés viszonylag könnyen értelmezhető és számszerüsíthető, mivel az inflációs rátára konkrét értékek is megadhatók. Nehezebb meghatározni a gazdasági növekedés fenntartható ütemét. Ez a szakirodalmi források szerint a potenciális kibocsátás növekedési üteme, amelynek meghatározásában nagy a bizonytalanság.

Bár a fenntarthatóság ismertetett értelmezése egyaránt érvényes az euróövezetre és az EU egészére is, a fenntarthatósággal szembeni követelmények nem teljesen ugyanazok. Az Európai Uniónak sok olyan kihívásra kell reagálnia, amely nem vagy nem közvetlenül érinti a GMU-t, de befolyásolja a gazdasági és monetáris integráció folyamatát. Ilyen az Egyesült Királyság kilépése az EU-ból, a populista pártok térnyerése és annak nagyszámú következménye, a Kelet és a Nyugat vitája a jogállamiságról, az északi és a déli tagállamok közötti bizalmi válság és a gazdasági konvergencia leállása, illetve megfordulása Dél-Európában, a menekültügy, az EU közvetlen és tágabb szomszédságában zajló háborúk, általában a biztonsági kockázatok erősödése a terrorista veszéllyel is összefüggésben és az Egyesült Államok globális szerepvállalásának szűkülése, a befelé fordulástól elválaszthatatlan protekcionista gazdaság- és külgazdasági politika térnyerése (Darvas [2018]). Ennek ellenére a GMU fenntarthatósága kiemelkedő mértékben határozza meg az európai integráció fennmaradását, a vele szembeni követelmények egyben az egész integráció fenntarthatóságának is a követelményei.

A gazdasági és monetáris unió fenntarthatóságát a hazai és nemzetközi szakirodalom többek között az optimális valutaövezet (Optimum Currency Area, OCA) kritériumainak való meg nem feleléssel, a monetáris integráció befejezetlenségével és a válságkezelő eszközök, intézmények és források hiányával hozta összefüggésbe.

\section{Az optimális valutaövezet és a fenntarthatóság}

Az optimális valutaövezet elmélete arra a kérdésre keresi a választ, hogy mi tesz alkalmassá egy országot vagy országcsoportot a gazdasági és monetáris unióban való részvételre. Eredeti formájában azt vizsgálta, hogy a nominális árfolyamok kiigazításának megszűnése után milyen helyettesítő egyensúlyteremtő mechanizmusok lehetségesek. Ez az elméleti keret tekinthető a monetáris integráció egyik alapjának. Definíciószerüen optimális valutaövezet (monetáris unió létesítésére alkalmas országcsoport) az, ahol teljesülnek a következő feltételek (Mundell [1961]). 
1. A termelési tényezők (munkaerő és tőke) piacai jól müködnek és rugalmasak, a termelési tényezők mobilak, ezáltal áruk képes alkalmazkodni a külső árváltozásokhoz.

2. Az övezet belső homogenitása olyan mértékü, hogy nem fenyegetik aszimmetrikus külső sokkok, illetve a részt vevő országok képesek gyorsan alkalmazkodni hozzájuk. Az aszimmetrikus külső sokk azt jelenti, hogy a gazdasági és monetáris uniót alkotó országok nagyságrendileg eltérő megrázkódtatásokat szenvednek el ugyanazon külső tényező hatására. Ennek az lehet az oka, hogy számottevően különbözik a részt vevő országok külgazdasági nyitottsága, exportjuk és importjuk áruösszetétele, az importált energiahordozóktól és az exportpiacoktól való függőségük, a külső finanszírozásra való ráutaltságuk mértéke, a gazdaság és a piacok szabályozása, intézményi struktúrája, a társadalmuk viselkedési formái és szokásai, és így tovább.

3. Megfelelö nagyságú költségvetési transzferek állnak rendelkezésre a különféle gazdasági zavarok elhárításához. Ebből a követelményből sok szakértő a költségvetési föderalizmus vagy legalábbis valamilyen költségvetési unió szükségességét vezeti le.

A tagállamok heterogenitása miatt a közös valuta bevezetésekor, az 1990-es évek végén a gazdasági és monetáris unió nem felelt meg az optimális valutaövezet kritériumainak. ${ }^{4}$ Ezért létrehozása előtt több neves, elsősorban amerikai szakértő fejezte ki kételyeit a gazdasági és monetáris unió hosszú távú életképességét illetően (például Feldstein [1997], [2012], Eichengreen [1996]).

Ezzel kapcsolatban nem hagyható figyelmen kívül, hogy a valutaövezethez történő csatlakozás lesz az, ami lehetővé teszi a kritériumok teljesíthetőségét különféle hatások és hatásmechanizmusok, például a tagállamok közötti kereskedelmi kapcsolatok erősödése révén (Benczes [2006]). Ez a kereskedelmi összefonódás az integráció endogén fejlődési útja.

Ha a részt vevő országok nem tesznek eleget az optimális valutaövezet feltételeinek, és az endogenitás lassan vagy egyáltalán nem érvényesül, akkor olyan, a monetáris unió müködését elősegítő intézményrendszert célszerủ kialakítani, amely ellensúlyozhatja a kereskedelmi integráció vontatottságát vagy akadozását (Mongelli [2008], idézi Szijártó [2017] 140. o.). Az intézményi integráció az optimális valutaövezet exogén elméleti megközelítése.

A kutatási eredmények szerint az intézményi integráció erösödése jóval nagyobb mértékü volt, mint a kereskedelmi integrációé (Szijártó [2017] 140. o.). Az intézményi integráció, ami mind a tagállami, mind a közösségi szintü intézményfejlesztést magában foglalta, mérsékelte a kereskedelmi integrációnak az optimális valutaövezet hiányosságaiból adódó korlátait.

Mindezek alapján önmagában az optimális valutaövezet kritériumainak való - részleges - meg nem felelés nem kérdőjelezi meg az euróövezet fenntarthatóságát.

\footnotetext{
${ }^{4}$ Ennek a szakirodalmi források segítségével történő igazolása szétfeszítené e tanulmány tartalmi és terjedelmi kereteit. Az elméletet sokan, sokféle irányban fejlesztették tovább; kimerítő összefoglalást ad erről Szijártó [2017].
} 
Legfeljebb arról lehet szó, hogy a GMU az optimális valutaövezethez képest alacsonyabb hatásfokkal, gyengébb gazdasági teljesítmény mellett müködhetett.

Az optimális valutaövezet elméletének megjelenése óta nagymértékben megváltoztak a mögötte meghúzódó körülmények (a szolgáltató szektor térnyerése, az egyes tagállamokban és a GMU szintjén végrehajtott intézményi reformok stb.), aminek nyomán következtetéseinek érvényessége gyengült. Ugyanakkor az optimális valutaövezet mint elméleti keretrendszer továbbra is alkalmas a GMU müködésének, azon belül fenntarthatóságának elemzéséhez. Az intézmények szerepét és jelentőségét kiemelö, exogén megközelítésen alapuló további kutatások eredményei nem csekély mértékben járulhatnak hozzá a GMU müködésének (és tegyük hozzá: fenntarthatóságának) javításához (Szijártó [2017] 143. o.).

Elemzésünk szempontjából annak van jelentősége, hogy a gazdasági és monetáris unió 2008-2009. évi nemzetközi pénzügyi válság által kiváltott működési zavarainak döntő része a dél-európai tagállamoknak (Olaszország, Portugália, Görögország, Ciprus, kisebb mértékben Spanyolország és Málta) tudható be, amelyek jelenleg sem felelnek meg teljes mértékben az optimális valutaövezet első két formális kritériumának. Ennél is fontosabb, hogy hosszú időn át a költségvetési fegyelem sem érvényesült náluk, amit főleg intézményi okokra lehetett visszavezetni. Mindezt súlyosbította a harmadik feltétel hiánya, azaz a 2008-2009. évi nemzetközi pénzügyi és gazdasági válságig megfelelő nagyságrendü költségvetési transzferek nem álltak rendelkezésre az euróövezet, illetve az EU szintjén a tagállamok esetleges gazdasági zavarainak az elhárításához.

\section{Válságkezelés és a GMU kiteljesítése}

A GMU fenntarthatósága többek között amiatt volt megkérdőjelezhető, hogy a monetáris integrációt nem egészítette ki költségvetési integráció. Amíg a monetáris politika közösségi szintre került, addig a nemzeti szuverenitás egyik lényeges elemének tekintett költségvetési politika tagállami hatáskörben maradt.

Ennek az aszimmetriának a részleges áthidalását, a tagállamok költségvetési fegyelemre való ösztönzését szolgálta egyrészt a maastrichti szerződésben rögzített konvergenciafeltételek közül a költségvetési kritériumok érvényre juttatására hivatott stabilitási és növekedési egyezmény szabályrendszere, amelyet már a legutóbbi válság előtt többször szigorítottak, másrészt a GMU tiltást tartalmazó három „pillére”.

Ami az utóbbit illeti, a kilépés tilalmával azt kívánták elkerülni, hogy a GMU laza árfolyamövezetté váljon, amelynek országok szerinti összetétele gyakran változik. Az államcsőd tilalmának garantálását, illetve kockázatának mérséklését szolgálta a pénzügyi egyensúlyhiányokkal küszködő GMU-tagállamok kimentésének, valamint ezzel összefüggésben az államadósság EKB által történő monetizálásának a tiltása. A három tilalom fegyelmezett költségvetési politikára volt hivatott késztetni az euróövezet tagállamait. Mögöttük többek között az a megfontolás húzódott meg, hogy prudens tagállami gazdaság- és költségvetési politika folytatása révén a gazdasági válságok megelőzhetők, ezért nincs szükség euróövezeti szintű ex post válságkezelö intézményekre és mechanizmusokra. A 2008-2009. évi nemzetközi pénzügyi és gazdasági válság és 
az azt követő szuverén adósságválság cáfolta ezt a feltételezést. A három tiltásra, amely szorosan összefügg egymással, az alapítók szerint a GMU hitelességének, végső soron a GMU fenntarthatóságának a garantálása miatt volt szükség.

A válság hatására a gazdasági és monetáris unió fenntarthatóságának biztosítására rövid távú válságkezelési intézkedéseket fogadtak el, ezzel párhuzamosan, részben ezt követően az integrációs intézményeket is szisztematikusan továbbfejlesztették, illetve újakat is létrehoztak.

A rövid távú válságkezelés jegyében a körülmények nyomására 2010-ben és 2011ben fellazították az államcsőd és az állami-közületi szektor kimentésének tilalmát. Így kerülhetett sor a görög államadósság átstrukturálására és közösségi szintű mentőalap létrehozására, aminek jelenlegi formája az európai stabilitási mechanizmus (részletesebben lásd például Losoncz [2014]).

Az Európai Központi Bank irányadó kamatlábának mérséklésével és egyéb intézkedésekkel (mennyiségi lazítás stb.) reagált a válságra, ezáltal nagy-, sőt később túlzott mértékben tehermentesítette a költségvetési politikát. Az EKB 2012. szeptember elején szükséghelyzetben korlátlan állampapírpiaci vásárlásra tett ígéretet, ami kimondatlanul a korábban elutasított végső hitelezői szerepkör („lender of last resort”) vállalásával volt egyenértékủ. Ez egyaránt szolgálta a megelőzést és adott esetben magát a válságkezelést.

A három tiltás a GMU fenntarthatóságának igen erős kritériuma volt. Az utólagos elemzés fényében az államcsőd és a kisegítés tilalmának (beleértve az EKB végső hitelezői szerepkörének a vállalását) - szigorú feltételek mellett történt - fellazítása nem veszélyeztette az euróövezet fenntarthatóságát; éppen ellenkezőleg: lehetővé tette a fennmaradását.

Ami az államcsődöt illeti, a szuverén adósságok átstrukturálása jelenleg is napirenden van. Az euróövezet GDP-arányos bruttó államadóssága 2004 előtt még 60 százalék alatt volt, a válság hatására azonban 2009-ben 80 százalék közelébe emelkedett. 2014-ben érte el a csúcsot közel 92 százalékos értékkel, ami 2017-ben 86,8 százalékra csökkent. Dél-Európában sokkal kedvezőtlenebb értékeket találunk: 2017ben az adósságállomány a GDP 176 százaléka volt Görögországban, 131 százaléka Olaszországban és 125 százaléka Portugáliában. Ezek az adóssághegyek visszafogják a gazdasági növekedést, ami az egész euróövezet növekedési kilátásait is rontja, és természetesen társadalmi következményeik is rendkívül súlyosak. Az államadósság görgetésének a költségei hosszú távon valószínüleg nagyobbak, mint egy fájdalmas egyszeri adósságleíráséi, ez utóbbinak azonban gyökeres költségvetési reformokkal kell párosulnia (Palánkai [2017] 43. o.).

Ettől függetlenül is a piaci fegyelem biztosítása mellett bizonyos esetekben szükség lehet a szuverén adósságok rendezett átstrukturálására, amelynek még hiányzik a mechanizmusa. Létrehozásakor célszerü figyelembe venni, hogy rugalmatlan szabályok esetén a piaci várakozások hirtelen láncreakciókat válthatnak ki. Nem becsülhetők alá az új mechanizmusra való átmenetnek a meglévő adósságra gyakorolt negatív hatásai sem.

Ugyancsak napirenden van az európai stabilitási mechanizmus továbbfejlesztése. Ennek olyan óvatossági - stabilitásorientált pénzügyi eszközzel való - kiegészítése 
javasolható, amely nemcsak ex post kezeli, hanem meg is előzi a válságot (Villeroy de Galhau [2018]). Az európai stabilitási mechanizmus pénzügyi forrásai között van már ilyen eszköz, amelyet azonban eddig még nem vetettek be, de amelyet tovább lehetne fejleszteni, például Európai Valutaalappá.

Az Európai Uniónak a válságra adott másik reakciója a szisztematikus intézményfejlesztés volt, amely a közös monetáris politika és a tagállami szintü költségvetési politika közötti ellentmondást volt hivatva mérsékelni a makrogazdasági és a költségvetési politikák koordinálása, valamint a költségvetési fegyelem és felügyelet megerősítése révén. Ennek főbb elemei a következők voltak:

- a 2011 végén hatályba lépett EURÓPAI SZEMESZTER elnevezésü gazdaságirányítási, gazdaságpolitikai koordinációs keretrendszer;

- a gazdasági kormányzást, beleértve a stabilitási és növekedési egyezmény szabályrendszerét, a korrigálás és a szankcionálás tekintetében erősítő HATOS JOGSZABÁLYCSOMAG;

- a stabilitási és növekedési egyezmény és az Európa 2020 stratégia kiegészítésére szolgáló, politikai kötelezettségvállalás formáját öltő EuRó PLUsz egyezmény;

- 2012 végén a GMU gazdasági pillérének - azon belül a gazdaságpolitikai koordinációnak és a gazdasági kormányzásnak - az erösítését célzó KÖLTSÉGVETÉSI EGYEZMÉNY;

- a költségvetési tervek figyelemmel kísérésére és a túlzott hiány korrekciójának biztosítására hivatott KETTŐS JOGSZABÁLYCSOMAG.

Ezek a gazdasági kormányzásra vonatozó közösségi jogszabályok, amelyek célja a megelőzés és a szankcionálás volt, és amelyek eredményessége eddig változónak bizonyult, a GMU fenntarthatóságának azonban csak szükséges, de nem elégséges feltételei. Ezzel összefüggésben fontos hangsúlyozni, hogy a tagállami intézmények és szabályozási keretek az integrációs struktúrák szerves elemei, ezért az európai uniós intézmények és szakpolitikák fejlesztésének feltétele a nemzeti intézmények és szakpolitikák alkalmazkodása (Palánkai [2017] 42. o.).

Az intézményfejlesztés a pénzügyi szabályozás szigorítására is kiterjedt, amelynek egyik eleme a makroprudenciális felügyelet erösítése volt. Ennek jegyében hozták létre 2010-ben az Európai Rendszerkockázati Testületet, amelynek feladatává a makroszintü kockázatok jelzését, megakadályozását és mérséklését, valamint a pénzügyi rendszer stabilitásának a felügyeletét tették. A mikroprudenciális felügyelet javítása érdekében 2011 elején a korábbi európai uniós szintű pénzügyi felügyelettel foglalkozó bizottságokat megerősítették és hatóságokká alakították. Közülük kiemelkedő fontosságú az Európai Bankfelügyeleti Hatóság. A mikroprudenciális felügyelet része még a tagállami felügyeletekből álló Pénzügyi Felügyeletek Európai Rendszere.

A 2012-ben elhatározott bankunió egy rendszerszintű problémára adott első rendszerszintű válasznak is tekinthető, bár megvalósítása nehezen halad. Ennek négy pillérét az európai uniós szintü pénzügyi felügyelet, az egységes szanálási mechanizmus és az ehhez kapcsolódó egységes szanálási alap, továbbá a közös bankbetét-biztosítási rendszer alkotja. Eddig nem született döntés az európai bankszanálási alap védőhálójáról (hogyan lehet emelni az alap forrásait, ha azok nem elegendök a bankok 
szanálására), a közös bankbetét-biztosítási alapról és a bankok államkötvény-állományának korlátozásáról. Ami a bankszanálási alapot illeti, szó van arról, hogy pótlólagos forrásait szükség esetén az európai stabilitási mechanizmus hiteleiből lehessen kiegészíteni. A közös betétbiztosítást a kedvezőbb költségvetési helyzetben lévő tagállamok (elsősorban Németország) ellenzik, azzal érvelve, hogy annak keretében a dél-európai országok (elsősorban Olaszország) bankbetéteseinek a kisegítési terheit másokkal együtt a német adófizetők viselnék. Ez a GMU transzferunióvá válásának a kockázatát is felidézné. Ugyanakkor az uniós védernyő gyengítheti a tagállamok kockázatmérséklő hajlandóságát. A bankok államkötvény-állományát azért kell korlátozni, mert egy tagállam költségvetésének a zavarai veszteségeket okozhatnak a bankoknak, ezáltal a költségvetési válság bankválságba is torkollhat (Darvas [2018] 17-18. o.). Ebből a szempontból különösen sérülékeny Olaszország.

A GMU stabilitásának és fenntarthatóságának erősítése föderális jellegü, azaz az euróövezetre vonatkozó külön költségvetés létesítését tenné szükségessé, amely az allokációs funkció mellett stabilizáló funkciót is ellátna. Az igényt az érintettek felismerték, a költségvetés jellegéről folynak a viták, a megvalósítást a tagállamok eltérő érdekei gátolják. A stabilitást és a fenntarthatóságot erősítő javaslatok között szerepel továbbá egy közös kibocsátású, kockázatmentes kötvény létrehozása az euróövezet számára, valamint a tagállamok pénzügyi kockázatainak földrajzi terítését lehetővé tevő tőkepiaci unió megvalósítása.

Ugyanakkor az eddigi intézményfejlesztési javaslatok nem kerestek választ a közös monetáris és a koordinált költségvetési politika tagállamok közötti divergenciákat erösítő hatásaira. Ami a monetáris politikát illeti, az EKB mindegyik GMU-tagállamra érvényes egységes kamatlába fékezte és továbbra is fékezi a gazdasági növekedést, és veszélyezteti az árstabilitást. Nevezetesen, a gyorsabb inflációjú és gyorsabban növekvő, alacsonyabb fejlettségi szintü - dél-európai - tagállamokban az EKB egységes nominális kamatlába reálértelemben negatív. Ez a válságig serkentette a növekedést és táplálta az inflációt, miközben ingatlan- és hitelpiaci buborékok alakultak ki, nőttek a munkaerököltségek, és felduzzadt a külkereskedelmi és a folyó fizetési mérleg hiánya.

A lassabban növekvő, alacsony inflációs rátájú tagállamokban (például Németországban) a reálkamatláb pozitív volt, ami visszafogta a gazdasági növekedést, erősítette a deflációs nyomást, és növekvő többletet generált a külkereskedelmi és a folyó fizetési mérlegben (részletesebben lásd Losoncz [2014]). Ez utóbbi korlátozta a deficites dél-európai tagállamok kivitelét, és rajta keresztül fékezte gazdasági növekedésüket. Az euróövezetben a nominális árfolyam-kiigazítás lehetőségének hiánya miatt alakultak ki, majd váltak tartóssá a külkereskedelmi és a folyó fizetési mérlegek deficitjei, illetve többletei.

Ugyancsak a nominális árfolyamok kiigazításának hiánya miatt voltak kénytelenek a dél-európai országok költség-versenyképességük helyreállítása érdekében restriktív bér- és költségvetési politikán alapuló, úgynevezett belső leértékeléshez folyamodni, ami viszont a társadalmi feszültségek kiéleződéséhez vezetett.

A belső leértékelést ösztönözte az „euró plusz” egyezmény is, mert a versenyképességet és a konvergenciát az euróövezetben az egységnyi munkaerököltség visszafogásával javasolta erősíteni (Podkaminer [2018] 16. o.). Ez a versenyképesség javítását szolgáló 
nominális leértékeléshez hasonló, versenypozíció növelését szolgáló belső leértékeléshez vezetett a tagállamokban, beleértve Németországot is, ahol ez nem vagy legfeljebb kismértékben volt indokolt. A belső leértékeléssel mint „gyógymóddal” a munkatermelékenység javitása állítható szembe, beleértve a termelési szerkezet felértékelését és az exportálható áruk és szolgáltatások minőségének a fokozását. Arra azonban nincs válasz, hogy hogyan lehetne mindezt hatékonyan ösztönözni tagállami és euróövezeti szinten, miként arra az utóbbi összefüggésében a lisszaboni stratégia és a többi hasonló kezdeményezés kudarca (optimista felfogásban: szerény eredménye) utal (uo.).

Az európai uniós intézmények és a tagállamok törekedtek a költségvetési politika prociklikusságának az enyhítésére, ezek a törekvések azonban nem változtattak a minden tagállamra kiterjedő, feltétel nélküli költségvetési konszolidáció kötelezettségén, ami indokolatlan. (Németországban például a magánszektor megtakarításai ellensúlyozhatják az államháztartási hiányt, ami nagyobb mozgásteret jelent a költségvetési politika számára.) Az egyes tagállamok sajátosságait figyelmen kívül hagyó általános költségvetési visszafogások további széttartó irányzatokat erősítettek és erősítenek az euróövezetben.

Podkaminer [2018] szerint az EU nem prosperálhat az elemzett két, magára kényszerített - gazdasági, elméleti és gyakorlati érvvel alig indokolható - monetáris és költségvetési korlát mellett. Változtatások nélkül ez hosszabb távon stagnáláshoz vezet, visszatérő társadalmi és politikai válságokkal, amelyek egyes tagállamok kilépését, sőt akár az euróövezet felbomlását is előidézhetik. Írása címében a szerző ezt nem tartja valószínütlennek. ${ }^{5}$

Podkaminer borús prognózisával szemben felvethetjük, hogy az említett integrációs szintü monetáris és költségvetési szabályozási korlátok a bemutatottnál kevésbé determinisztikusak. Így a negatív reálkamatláb által kiváltott hatásokat fegyelmezett gazdaság-, illetve költségvetési politikával lehet(ett volna) ellensúlyozni. Németország esetében a belső leértékelés alternatívája lehetett volna, ha kihasználja az ország nem költség- és árjellegü versenyelönyeit (kutatás-fejlesztés, innováció stb.).

\section{A reformok és a fenntarthatóság közötti néhány összefüggés}

\section{A GMU fenntarthatóságának dimenziói}

Abból kiindulva, hogy a fenntartható integrációt tartós ellenálló képesség jellemzi, és politikailag elfogadható, a gazdasági és monetáris unió fenntarthatóságának a tagállamokra vonatkozóan a következők a feltételei: fenntartható gazdasági növekedés, a modernizáció változatainak a figyelembevétele és a kormányok elkötelezettsége a demokratikusan fenntartható reformok mellett (Begg és szerzötársai [2016]).

A fenntartható GazdAsági NÖVeKedÉs a GMU zavartalan müködésének elengedhetetlen feltétele, amelyet elsősorban tagállami szinten kell megteremteni. A kérdés az, vajon lehet-e (és ha igen, akkor milyen módon) ösztönözni a gazdasági

\footnotetext{
${ }^{5}$ Economic disintegration of the European Union: not improbable.
} 
növekedést a költségvetési konszolidációval és az adósságállomány csökkentésével egyidejüleg úgy, hogy közben biztosított legyen a hosszú távú fenntarthatóság. Erre nincs általános recept. Az idézett szerzők szerint a feladat végrehajtását segíthetik a tagállamok szintjén az államháztartásból, az EU szintjén pedig a stratégiai beruházási alapból finanszírozott beruházások. Megjegyzendő, hogy az utóbbiaknak az alap korlátozott forrásellátottsága szabhat gátat.

Az idézett szerzők szerint a MODERNIZÁCIÓT SZOLGÁLÓ TAGÁLLAMI REFORMOKNAK a rövid távra szóló intézkedések és a hosszú távú célok összhangjának megteremtésével az integráció hatékonyabb formáját kell eredményezniük. A Nemzetközi Valutaalap, az OECD és az európai uniós intézmények elemzéseinek és gazdaságpolitikai javaslatainak a középpontjában hosszabb idő óta az államháztartási, illetve szerkezeti reformok állnak. Ezektől várják a potenciális kibocsátás ütemének a gyorsulását. Tény, hogy eddig sem az EU, sem az euróövezet nem talált kielégítő megoldást a tagállamok társadalmi, politikai és gazdasági heterogenitásának kezelésére.

Benczes-Kutasi [2010] szerint a gazdasági vagy pontosabban az államháztartási reform közjószágnak tekinthető, mert végrehajtása után a társadalom egészének a helyzete javul, és senkit sem lehet (nem is érdemes) kizárni a reform hasznaiból. A nehézség a potyautas-magatartás lehetősége: a reform hasznából úgy is részesülhet az egyén, hogy nem járul hozzá annak költségeihez. Ez a magyarázata annak, hogy sok reform részlegesen, felhígítva valósul meg, vagy az érintettek ellenállása miatt teljes mértékben kudarcot vall. Célszerü megkülönböztetni egymástól a rövid távú költségvetési konszolidációt és a hosszabb távon végrehajtott szerkezeti reformokat. Bokros Lajos parametrikus és paradigmatikus reformokat definiált. A parametrikus reformok a rendszer egyes jellemzőinek átalakítását célozzák, más szavakkal: a szabály és mérték (mennyiségi és arányossági) kiigazítására irányulnak. A paradigmatikus reformok a meglévő rendszer logikája egyes elemeinek, a struktúra jellegének a lényegi, minőségi felülvizsgálatát jelentik.

Ehhez hozzáfüzhetjük, hogy sem a tagállami reformok nem helyettesíthetik az euróövezeti szintűeket, sem pedig az euróövezeti reformok a tagállamiakat. A két szint feltételezi, kiegészíti és erősíti egymást. A tagállamok gazdaságpolitikai szuverenitásának szem előtt tartása mellett az euróövezet fenntarthatóságának erősítését szolgáló közös stratégia része lehet, hogy egyes tagállamokban (például Franciaországban) több reformot szükséges végrehajtani, míg más tagállamokban, ahol nagyobb a mozgástér (például Németországban és Hollandiában), expanzívabb költségvetési és jövedelempolitika is folytatható (Villeroy de Galhau [2018]).

A reformok nagy valószínűséggel akkor lesznek eredményesek, ha a KORMÁNYOK ELKÖTELEZIK MAGUKAT mellettük, és demokratikusan valósítják meg őket mind tagállami, mind európai uniós szinten. A GMU-ban bevezetett és tervezett reformok nem fenntarthatók, ha rákényszerítik őket a tagállamokra. Ideális esetben az Európai Bizottság által kikényszerített költségvetési fegyelem helyét fokozatosan átveheti az önkéntes politikai kötelezettségvállalás, amelyhez a tagállamok által magukénak érzett közös szabályok és várakozások kapcsolódnak. Mindennek szerves része és feltétele az elszámoltathatóság (Begg és szerzőtársai [2016]). A tagállami reformok végrehajtását különféle érdekcsoportok akadályozzák. 
A kormányzati elkötelezettséghez hozzá lehet füzni az EU-ból való brit kiválásból levonható azon következtetést is, hogy a gazdasági és monetáris unió fenntarthatóságához elengedhetetlen, hogy a jogokkal és kötelezettségekkel járó tagságból adódóan az egyes tagállamok folyamatos erőfeszítésekkel járuljanak hozzá a közös vívmányokhoz (Bongardt-Torres [2016]). Ez a kategorikus imperatívusznak tekinthető következtetés és törekvés helyes, gyakorlati megvalósítása azonban sokféle - elsősorban politikai - tényezőtől függ. Érvényesítése különösen nehéz olyan időszakban, amikor az euroszkeptikus és eurofób populista politikai erők befolyása jelentős.

\section{Fenntartható gazdasági konvergencia}

Nemcsak az euróövezet, hanem az egész Európai Unió fenntarthatósága kiemelkedő mértékben függ a kohéziótól, amelynek leglényegesebb eleme a tagállamok közötti reálkonvergencia. Ez nem más, mint „az a hosszú távú folyamat, amely az alacsonyabb jövedelemszintű országok egy före jutó reál GDP-szintjét a magas jövedelmü országok közelébe hozza" (Diaz del Hoyo és szerzőtársai [2017] 4. o.). A reálkonvergenciából mindenekelőtt a felzárkózó országok polgárai profitálnak.

Fenntarthatósági megközelítésben az euróövezeti tagállamoknak a konvergencia eléréséhez javítaniuk kell intézményeik minőségét. Ez utóbbin a gazdasági növekedést ösztönző kormányzati szabályok és a sokkokkal szembeni ellenálló képességet javító gazdasági struktúrák értendők. Ezek milyenségére nincsenek általánosan érvényes szabályok; figyelembe kell venni az egyes tagállamok sajátosságait. A fenntartható konvergenciának része a maastrichti szerződésben lefektetett nominális konvergenciának történő megfelelés is. A nominális konvergencia támogathatja, de akadályozhatja is a reálkonvergenciát.

A fenntartható konvergencia a gazdasági és monetáris unió működését is elősegíti. Így hozzájárul az optimális valutaövezet feltételeinek a létrejöttéhez, válsághelyzetekben a destabilizáció megakadályozásához, és támogatja a közös monetáris politikát, amely egyébként is túlterhelt (Diaz del Hoyo és szerzőtársai [2017] 5. o.). Modellszámítások szerint a hosszú távú konvergencia legfőbb hajtóereje a munkatermelékenység és a teljes tényezőtermelékenység javulása volt.

Az 1999 és 2016 közötti időszakban a reálkonvergencia jelentős mértékben előrehaladt a balti köztársaságokban és Szlovákiában. Ezzel szemben az egy főre jutó GDP tekintetében az EU-átlagtól mért különbség fennmaradt Szlovénia és Spanyolország esetében, Görögország, Ciprus, Portugália és Olaszország esetében pedig egyenesen növekedett a lemaradás.

Az euróövezetben az intézményi minőség színvonala és időbeli változása szoros korrelációt mutat az egy főre jutó GDP növekedési ütemével. Hasonló jellegű kapcsolat érvényesül a termék- és munkaerőpiacok rugalmassága és ellenálló képessége, valamint az egy főre jutó GDP dinamikája között. Mindez koncentráltan jellemezte Görögországot, Spanyolországot, Portugáliát és Olaszországot (Diaz del Hoyo és szerzőtársai [2017] 9. o.). Így nem meglepő, hogy ezeknek az országoknak a konvergenciateljesítménye gyenge. 


\section{A gazdasági sokkokkal szembeni ellenálló képesség}

A szuverén adósságválság kezelése és a szélesebb értelemben vett válságkezelés tanulságai nyomán - a gazdasági és monetáris unió fenntarthatóságával összefüggésben az utóbbi két-három évben előtérbe került az euróövezet jövőbeli gazdasági sokkokkal szembeni ellenálló képességének növelése.

Az Európai Bizottság definíciója szerint

„a gazdasági ellenálló képesség az országok azon képessége, hogy ellenálljanak a sokkoknak, és [gazdaságuk] a recesszió után gyorsan visszaálljon a potenciális kibocsátás szintjére. Az ellenállóképes gazdasági struktúrák megakadályozzák, hogy a gazdasági sokkok jelentős és állandó hatást gyakoroljanak a jövedelmekre és a foglalkoztatási szintekre, ezáltal mérséklik a gazdasági fluktuációkat." (EC [2017b] 2. o.)

Az ellenálló képességnek három eleme van: a sebezhetőség, a sokkabszorpciós kapacitás és a gazdaság sokk utáni helyreállítási képessége. ${ }^{6}$

- A SEBEZHETősÉG arra utal, hogy egy sokk érint-e egy gazdaságot, ha igen, menynyire erősen. A teljesség igénye nélkül: a sebezhetőség függ a gazdasági szerkezettől, a követett gazdaságpolitikától, a pénzügyi szektor és az értékpapírpiacok állapotától, valamint a nem pénzügyi szektor sajátosságaitól.

- Az ABSZOR PCIÓs KAPACITÁs a gazdaság azon képessége, hogy ellensúlyozni tudja egy sokk közvetlen hatását, és képes minimalizálni a közvetlen kibocsátási veszteséget és a munkahelyek megszünését. A sokk hatásainak a gazdaságban való szétterítése történhet automatikus stabilizátorok, rugalmas bérek és árak, valamint hitelek és kockázatmegosztás segítségével.

- A gazdASÁg helYREÁlLítÁsi kAPACITÁsa az a képesség, amely biztosítja a korábbi állapothoz való visszatérést, ha a sokkok átmeneti jellegűek, illetve az erőforrások zökkenőmentes reallokációját, ha a sokkok tartós hatásúak.

Az Európai Bizottság az ellenálló képességet átfogó prioritásként fogalmazza meg. A 2018. évi növekedési jelentés szerint a tagállamok a beruházások ösztönzését, a közpénzek magánberuházást generáló hatásának fokozását és az üzleti környezet javítását célzó szerkezeti reformjai segíthetik a gazdasági ellenálló képesség fokozását, és jótékony hatást gyakorolhatnak hosszú távon a gazdasági konvergenciára és a társadalmi különbségek mérséklésére, enyhíthetik a konjunktúraciklusok ingadozását, és megakadályozhatják a mély és elhúzódó recessziót (EC [2017a] 3-4. o.).

A 2018. évi növekedési jelentés külön részben foglalkozott az ellenálló képesség és a konvergencia közötti összefüggésekkel. Kiindulópontja az volt, hogy a tagállamok közötti hatékony konvergencia hiánya nem csekély mértékben hozható kapcsolatba a GMU müködési problémáival. A jelentés a GMU hosszú távú sikere lényeges elemének tartja, hogy a tagállamoknak egyre rugalmasabb az ellenálló képességük.

A dokumentum szerint a gazdaság sokkelnyelő kapacitását befolyásolja a pénzügyi piacokon keresztül történő kockázatmegosztás. A belső piac a konvergencia legfőbb

\footnotetext{
${ }^{6}$ A következők forrása: EC [2017b] 5. o.
} 
eszközének bizonyult. A tőkével megfelelően ellátott bankszektor és a fejlett tőkepiaci unió szintén hozzájárul a kockázatmegosztáshoz és a sokkabszorpciós kapacitás erősítéséhez. A megfelelően müködő munkaerőpiaci intézményeknek, valamint a kompetitív termék- és szolgáltatáspiacoknak szintén fontos szerepük van a sokkhatások kezelésében és a hosszú távú strukturális változásokban. A határozott, fenntartható és időben megfelelően szakaszolt, a hosszú távú kihívásokat megválaszoló szerkezeti reformok szintén erősítik a gazdaságok ellenálló képességét és a fenntartható reálkonvergenciát. Mindezt a jelentés kiegészíti a termelékenység javítását és a potenciális kibocsátás növekedését ösztönző közép- és hosszú távú szakpolitikákkal és megfelelő makrogazdasági politikával (EC [2017a] 7-8. o.).

Az Európai Bizottság dokumentumai szerint az alkalmazkodóképesség elsősorban tagállami szinten értelmezhető, amelyet azonban integrációs szintű intézkedések is erősíthetnek, azaz ha az egyes tagállamok erősítik gazdasági ellenálló képességüket, akkor különféle szinergikus hatások eredményeként az euróövezeté is erösödni fog.

Az Európai Bizottság olyan struktúrák és képességek kialakítását célozza, amelyek felkészítik a tagállamokat a sokkhatások kezelésére. A megelőzésen alapuló azon intézményi mechanizmusok és struktúrák azonban, amelyeken a gazdasági és monetáris unió alapul, nem voltak képesek elejét venni a nemzetközi pénzügyi és gazdasági válság okozta recessziónak és a szuverén adósságválságnak. Az ellenálló képesség fogalma sem tartalmaz explicit módon válságkezelő, illetve stabilizációs mechanizmusokat az euróövezet szintjén. Ugyanakkor a tagállamokra vonatkozó szabályok sem nyújtanak elegendő ösztönzést anticiklikus költségvetési politika folytatására. Ennek következtében a tagállami költségvetési politika túlterheltsége fennmarad, aminek a legsúlyosabb következményei a munkaerőpiaci politika terén jelentkezhetnek (Theodoropoulou [2017]).

A teljes képhez hozzátartozik azonban, hogy - miként korábban volt róla szó - egyrészt létezik GMU-szintű válságkezelési eszköz az európai stabilitási mechanizmus formájában, amelynek továbbfejlesztése folyamatban van, másrészt vannak törekvések újak létrehozására (a bankunió egyes pillérei stb.).

A koncepció nem ad választ arra a kérdésre, hogy az a potenciális kibocsátás, amihez vissza kívánnak térni, optimális-e egyáltalán. Az ellenálló képességet különböző gazdaságpolitikák segítségével lehet elérni, amelyek esetenként egymás hatását gyengíthetik. Például a sebezhetőséget mérsékli az államadósság csökkentése, az utóbbit célzó költségvetési restrikció viszont hátrányosan érintheti az abszorpciós kapacitást és az egyének ellenálló képességét, ha a kiadások visszafogása a munkanélküli-segélyeket is érinti. Az egyes tagállamokban a folyó fizetési mérleg többletéhez, másokban hiányához vezetö, aszimmetrikus tőkeáramlások elkerülése aligha lenne összhangban a közös pénz intézményével, a gazdasági és monetáris unió létével (Theodoropoulou [2017]).

\section{Összefoglalás, következtetések}

A fenntarthatóság az Európai Unióban, azon belül a gazdasági és monetáris unióban is kiemelkedő fontosságú hosszú távú gazdaság-, környezet- és társadalompolitikai célkitüzés, amely az elsődleges joganyag része. A fogalom - a GMU tartós 
fennmaradásaként történő felfogása esetén - a felbomlás és az integrálódás mint két szélső pont között helyezkedik el. Semlegesnek tekintve mind a visszafejlődésként értelmezhető dezintegrálódást, mind a progresszív integrálódást lefedi, bár hallgatólagosan a mindenkori állapot fenntartását mint minimális követelményt értik rajta.

A fenntarthatóság elemzését nehezíti, hogy érvényre jutását utólag, a jelenben végrehajtott vagy végrehajtani tervezett intézkedések és cselekvések megvalósítását követően lehet megállapítani. Ezeknek a lépéseknek a kimenetele nagy bizonytalanság mellett jelezhető előre. Mindenesetre az euróövezet az utóbbi két évtizedben megjelent, nagyszámú borúlátó értékelés ellenére nem bomlott fel, hanem fenntarthatónak bizonyult. Ebből önmagában véve természetesen nem következik, hogy a jövőben is életképes marad és fennáll.

Az operacionalizálással kapcsolatos korlátok ellenére a fenntarthatóság mint kutatási módszer, követelmény, vezérelv és cselekvési vezérfonal hasznos elemzési szempont, eszköz és analitikus keret lehet az EU és azon belül az euróövezet esetében is, bár nem kifejezetten erre jött létre. A fenntarthatóság cselekvésre való felhívásként is értelmezhető. Érvényre jutása nem automatikus, megvalósítása (például a tagállami szerkezeti reformok végrehajtása és a közös vívmányokhoz való hozzájárulás) elkötelezettséget és folyamatos erőfeszítéseket igényel a tagállamoktól és gazdasági szereplőiktől.

Az utólagos elemzés fényében a fenntarthatóság dinamikus kategória, tartalma jelentős változásokon ment keresztül, alkalmazkodott az új kihívásokhoz és feltételekhez. Az euróövezet megalapítása utáni tíz évben még az volt az uralkodó felfogás, hogy a kilépésnek, az államcsődnek és a tagállamok állami-közületi szektora kisegítésének tiltása a GMU fenntarthatóságának a feltétele. A 2008-2009. évi nemzetközi pénzügyi és gazdasági válság hatására az utóbbi két pillér fellazítása nem gyengítette a GMU fenntarthatóságát, hanem éppen ellenkezőleg: erősítette, sőt feltétele volt annak.

Bebizonyosodott, hogy bár megfelelö intézményi struktúrák kialakításával (például a gazdasági kormányzás, valamint a makro- és mikroszintű pénzügyi felügyelet erősítése révén) az esetleges válságok hatása enyhíthető, mégis szükség lehet megfelelö forrásokkal rendelkező, integrációs szintü megelőző és ex post korrekciós válságkezelő eszközökre és mechanizmusokra. Ilyennek tekinthető az európai stabilitási mechanizmus továbbfejlesztése, a bankunión belül a bankszanálási mechanizmus és alap, továbbá az Európai Unióra kiterjedő betétbiztosítás létrehozása, valamint a jegybankok államkötvény-állományának korlátozása. Az erröl folyó viták lezárását, a hosszú távon érvényes megoldás kidolgozását és elfogadását nagyban hátráltatják az euróövezet tagállamainak eltérő érdekviszonyai. Megvalósításuk lényeges hozzájárulás lehet az euróövezet fenntarthatóságához.

Az optimális valutaövezet követelményeinek való kezdeti teljes vagy részleges meg nem felelés sem kérdőjelezte meg a gazdasági és monetáris unió fenntarthatóságát, legfeljebb az optimálisnál alacsonyabb hatásfokú müködését eredményezhette. A kereskedelmi integrációnak az optimális valutaövezet hiányosságaiból adódó korlátait mérsékelte, sőt nagymértékben ellensúlyozta az intézményi integráció fejlődése.

A tagállamok és az európai uniós intézmények eddig nem találtak megnyugtató választ az - Európai Központi Bank minden tagállamra érvényes nominális 
kamatlába és a koordinált költségvetési politika egyensúlyt helyreállító kötelezettsége által kiváltott - széttartó fejlődési irányok kiküszöbölésére. A versenyképesség belső leértékelés megtiltása révén történő javítása illúzió, a munkatermelékenység, a termelési szerkezet és az exportálható áruk és szolgáltatások minőségjavításának ösztönzése mint konstruktív kitörési lehetőség tagállami és euróövezeti szinten egyaránt megoldatlan. E problémák rendezésének halogatása stagnáláshoz, végső soron az euróövezet fenntarthatóságának gyengüléséhez vezethet.

Nincs garancia arra, hogy ha a tagállamok eleget tesznek a fenntarthatósággal, fenntartható fejlödéssel szembeni követelményeknek, akkor ezzel maga az Európai Unió, illetve a GMU is fenntartható fejlődési pályára kerül. Az EU fenntartható fejlődési stratégiája, illetve a tagállamok fenntartható fejlődését biztosító és előmozdító nagyszámú jogszabály és szakpolitikai lépés nem azonosítható automatikusan magának az Európai Uniónak, azon belül az euróövezetnek a fenntarthatóságával.

Ugyanakkor általános irányzatként kirajzolódik, hogy a tagállami szintü intézkedések nagyobb mértékben járulnak hozzá a GMU fenntarthatóságához, mint az integrációs szintűek. A fenntartható gazdasági konvergencia kiemelkedő mértékben függ a felzárkózó tagállamok intézményeinek a minőségétől.

Az integráció fenntarthatósága, valamint az európai uniós és tagállami fenntarthatósági stratégiák között kölcsönhatás áll fenn. A közösségi és uniós fenntarthatósági stratégiák erősíthetik magának az integrációnak a fenntarthatóságát, az integráció fenntarthatóságának javulása pedig a tagállamokét.

Az integrációs szintű szabályozás, mechanizmus és intézményrendszer elsődleges célja a megelőzés, és csak végső esetre tartalékolja a válságkezelést. Az integrációs szintű védernyő meglehetősen gyenge. Akkor hatékony, ha nem vállalja magára teljes mértékben a kockázatokat, hanem egyrészt csökkenti, másrészt megosztja őket a gazdasági szereplők között, ügyelve arra, hogy ne szorítsa háttérbe a piac fegyelmező erejét. Elfogadható arányt kell találni továbbá a felelősség és a szolidaritás között, és elejét kell venni a potyautas-magatartásnak.

A GMU létrehozása politikai döntés eredménye volt, nem kizárólag gazdasági mérlegelésé. A tagállamok az utóbbi 10-15 évben sok politikai tőkét fektettek a gazdasági és monetáris unió felépítésébe és működtetésébe, amit nem kívánnak elveszíteni. Az euró melletti politikai elkötelezettség erős, de nagyszámú jel szerint eddig nem volt elegendő az erőteljesebb pénzügyi integrálódás elősegítéséhez, vagy legalábbis ellentmondásokkal terhelt volt ez a támogatás. Ennek alapján az euróövezet felbomlása nem zárható ugyan ki, de ennek a valószínüsége igen kicsi. Ebben az is szerepet játszik, hogy a tagállamok integráltsága kiemelkedő mértékü.

Megalapozottan vélelmezhetjük, hogy a nagy államadóssággal rendelkező déleurópai országcsoport, azon belül elsősorban Olaszország nélkül az euróövezet fenntarthatóbb lenne. Ezeknek az országoknak a kiválása, illetve a kizárása azonban jogilag nem lehetséges, ilyen politikai akarat sem létezik a GMU-ban. Az euróövezet fenntarthatósága ezért nagymértékben függ a dél-európai országok által végrehajtandó szerkezeti reformoktól. A külső feltételrendszer várható romlása, azon belül a kamatlábak emelkedése még sürgetőbbé teszi ezt. A dél-európai országok alkalmazkodását az euróövezet többi tagállamának is célszerü segítenie. 


\section{Hivatkozások}

Begg, I.-Bongardt, A.-Nicolaïdis, K.-Torres, F. [2016]: EMU and sustainable integration. London School of Economics and Political Science, https://doi.org/: 10.1080/ 07036337.2015.1079375.

BenCzes István [2006]: Az optimális valutaövezetek elmélete: Bevezetés. https://www. researchgate.net/publication/267927396_Az_optimalis_valutaovezetek_elmelete_ Bevezetes. Megjelent még: Palánkai Tibor (szerk.) [2011]: A globális és regionális integráció gazdaságtana. Akadémiai Kiadó, Budapest.

Benczes István-Kutasi Gábor [2010]: Költségvetési pénzügyek. Hiány, államadósság és fenntarthatóság. Akadémiai Kiadó, Budapest.

Bongardt, A.-Torres, F. [2016]: The Political Economy of Brexit: Why Making It Easier to Leave the Club Could Improve the EU. Intereconomics, Vol. 51. No. 4. 2014-2019. o. https:// doi.org/10.1007/s10272-016-0605-z.

Darvas Zsolt [2018]: A Brexit hatása az európai integrációs folyamatokra. A Világgazdasági Tudományos Tanács szeptember 20-i ülésére készített tanulmány, kézirat. 26 o.

Diaz del Hoyo, J. L.-Dorucci, E.-Heinz, F. F.-Muzikarova, S. [2017]: Real convergence in the euro area: a long-term perspective. European Central Bank Occasional Paper Series, No. 203. https://www.ecb.europa.eu/pub/pdf/scpops/ecb.op203.en.pdf?8ff80dd3a3b58 f231105f3e4835b2928.

EC [2008]: EMU@10 Successes and challenges after ten years of Economic and Monetary Union. European Economy, No. 2. European Commission, Brüsszel, http://ec.europa.eu/ economy_finance/publications/pages/publication12682_en.pdf.

EC [2017a]: Annual Growth Survey, 2018. European Commission, Brüsszel, november 22. COM(2017) 690 final, https://ec.europa.eu/info/sites/info/files/2017-comm-690_en_0.pdf.

EC [2017b]: Economic Resilience in the EMU. Note for the Eurogroup. European Commission, Brüsszel, szeptember 13. https://www.consilium.europa.eu/media/23535/eurogroup15-september-item1-com-note-economic-resilience-in-emu.pdf.

Eichengreen, B. [1996]: EMU: An Outsider's Perspective. Center for International and Development Economics Research [CIDER] Working Paper, C96-079, University of California at Berkeley.

Feldstein, M. [1997]: The Political Economy of the European Economic and Monetary Union: Political Sources of an Economic Liability. Journal of Economic Perspectives, Vol. 11. No 4. 23-42. o. https://doi.org/10.1257/jep.11.4.23.

Feldstein, M. [2012]: The failure of the euro. The Little Currency that Couldn't. Foreign Affairs, Vol. 91. No. 1. 105-116. o.

Halmai Péter (szerk.) [megjelenés alatt]: Tagállami integrációs modellek. Dialóg Campus Kiadó, Budapest.

Losoncz MikLós [2014]: Az államadósság-válság és kezelése az EU-ban. Tri-Mester Kiadó, Tatabánya.

Mongelli, F. P. [2008]: European Economic and Monetary Integration and the Optimum Currency Area Theory. European Commission, Economic Papers, No. 302. https://doi. org/10.2765/3306.

Mundell, R. [1961]: A theory of optimum currency areas. American Economic Review, Vol. 51. No. 4. 657-664. o.

PalánKai Tibor [2017]: Javaslat az integrációelmélet újragondolására. Európai Tükör, 20. évf. 1. sz. 25-47. o. 
Pisani-Ferry, J. [2002]: Balancing the stability pact. Financial Times, június 26. 15. o.

Pisani-Ferry, J.-PAdoA-Schioppa, T. [2018]: Euro area reform: An anatomy of the debate. Centre for Economic Policy Research, https://cepr.org/sites/default/files/policy_insights/ PolicyInsight95.pdf.

PodkAminer, L. [2018]: Economic disintegration of the European Union: not improbable. WIIW Monthly Report, No. 10. 11-17. o. https://doi.org/10.1556/032.2016.66.s1.3.

Reinhart, C. M.-Rogoff, K. S. [2010]: Growth in a Time of Debt. NBER Working Paper, No. 15639. http://www.nber.org/papers/w15639.

Reinhart, C. M.-Rogoff, K. S. [2011]: This Time is Different - Eight Centuries of Financial Folly. Princeton University Press, Princeton-Oxford.

Reinhart, C. M.-Rogoff, K. S. [2013]: Financial and Sovereign Debt Crisis: Some Lessons Learned and those Forgotten. IMF Working Paper, WP/13/266. https://www.imf.org/ external/pubs/ft/wp/2013/wp13266.pdf.

SzIJÁrtó Norbert [2017]: Az optimális valutaövezetek elmélete. Köz-Gazdaság, 12. évf. 3. sz. 129-148. o. http://real.mtak.hu/80702/1/Koz_Gazdasag_2017_3_Szijarto_Norbert_u.pdf. Theodoropoulou, S. [2017]: The pitfalls of pursuing economic resilience in the Eurozone. London School of Economics and Political Science, http://blogs.lse.ac.uk/europpblog/ 2017/12/05/the-pitfalls-of-pursuing-economic-resilience-in-the-eurozone/.

Villeroy de Galhau, F. [2018]: The sustainability of European Monetary Union and institutional reform. Speech at The ECB and Its Watchers XIX Conference, organised by the Institute for Monetary and Financial Stability. Frankfurt am Main, március 14. https:// www.bis.org/review/r180419a.pdf.

WCED [1987]: Our Common Future. Report of the World Commission on Environment and Development. Brundtland report. Oxford University Press. Magyarul: Közös jövőnk. A Brundtland-jelentés. Mezőgazdasági Könyvkiadó, Budapest, 1988. 